\title{
Evaluation of plasticity and radiopacity of elastic separators by means of traction tests and radiography
}

Danielle Frota Mendes', José Euclides Nascimento ${ }^{2}$, Adriano Francisco de Lucca Facholli², Maurício de Alencar Casa ${ }^{2}$, Luciano da Silva Carvalho ${ }^{3}$, Kikuo Sato $^{3}$

Introduction: Elastic separators are widely used in the orthodontic clinic, in different sizes and thicknesses. Their function is to promote the separation between the teeth that will receive orthodontic bands, however, when subgingivally lost, they may cause periodontal problems and, ultimately, cause tooth extraction. Objective: Concerned not only about their function but also about their properties, this experimental work was performed in order to evaluate, with a clinical perspective, the plasticity and radiopacity of the elastic separators, usually used in orthodontic clinic, through physical traction tests and radiographs. Methods: Six different brands were analyzed and divided in two groups: extruded separators (American Orthodontics, GH, Morelli Blue and Morelli Green) and modular separators (Abzil, Dentaurum, GAC, Blue Modular Morelli and Green Modular Morelli). The plasticity was evaluated after physical traction tests, stretching the separators to 3 times their initial diameter. While the radiopacity was assessed using x-rays. Results: When stretched to three times their inner diameter (ID), the extruded separators American Orthodontics, GH, Morelli Blue and Morelli Green and the modular ones Dentaurum, Morelli Blue Modular and Morelli Green Modular, presented elastic deformation, recovering their original inner diameter. The modular separators from Abzil and GAC showed permanent plastic deformation. With respect to radiopacity, the Abzil, American Orthodontics, Dentaurum, GAC and GH separators were radiopaque. Conclusion: Correlating the results concerning the plasticity and radiopacity, the separators which showed the most satisfactory results on both tests were, among the extruded separators, American Orthodontics and GH, and among the modular separators, GAC and Dentaurum.

Keywords: Orthodontics. Elastomers. Tensile strength. Radiology.

Introdução: os separadores elásticos são amplamente usados na clínica ortodôntica, em diferentes tamanhos e espessuras. Sua função é promover a separação entre os dentes a serem bandados, mas, quando subgengivalmente perdidos, podem causar problemas periodontais e, em última instância, a extração do dente. Objetivo: preocupados não somente com a sua função, mas também com as suas propriedades, realizou-se esse trabalho experimental, que objetiva avaliar, com um enfoque clínico, a plasticidade e radiopacidade dos separadores elásticos, comumente utilizados na clínica ortodôntica, por meio de testes físicos de tração e radiográficos. Métodos: analisou-se seis diferentes marcas de separadores elásticos, as quais foram divididas em dois grupos: separadores extrudados (American Orthodontics, GH, Morelli Azul e Morelli Verde) e separadores modulares (Abzil, Dentaurum, GAC, Morelli Modular Azul e Morelli Modular Verde). A plasticidade foi avaliada por meio de testes físicos de tração, alongando-se os separadores três vezes o seu diâmetro inicial, enquanto a radiopacidade dos separadores foi avaliada por meio de tomadas radiográficas. Resultados: quando alongados três vezes o diâmetro interno (DI), os separadores extrudados American Orthodontics, GH, Morelli Azul e Morelli Verde e os modulares Dentaurum, Morelli Modular Verde e Morelli Modular Azul tiveram deformação elástica, recuperando seu diâmetro interno. Os separadores modulares Abzil e GAC apresentaram deformação plástica permanente. Com relação à radiopacidade, os separadores Abzil, American Orthodontics, Dentaurum, GAC e GH apresentaram-se radiopacos. Conclusão: correlacionando os resultados concernentes à plasticidade e radiopacidade, os separadores que apresentaram os resultados mais satisfatórios nos dois quesitos foram, dentre os separadores extrudados, American Orthodontics e GH, e, dentre os separadores modulares, GAC e Dentaurum.

Palavras-chave: Ortodontia. Elastômeros. Resistência à tração. Radiologia.

» The author reports no commercial, proprietary or financial interest in the products or companies described in this article.

${ }^{1}$ Specialist in Orhtodontics.

${ }^{2}$ Assistant Professor, Specialization Program in Orthodontics, Professional Development School (EAP) - Paulista Association of Dental Surgeons (APCD) São Paulo and Sorocaba.

${ }^{3}$ Head of the Specialization Program in Orthodontics, EAP - APCD - São Paulo.
How to cite this article: Mendes DF, Nascimento JE, Facholli AFL, Casa MA, Carvalho LS, Sato K. Evaluation of plasticity and radiopacity of elastic separators by means of traction tests and radiography. Dental Press J Orthod. 2012 Nov-Dec;17(6):23.el-10.

Contact address: Danielle Frota Mendes

Rua Melo César, 60 - Cidade dos Funcionários - Fortaleza/CE - Brazil CEP: 60823-110 - E-mail: dani.frota@terra.com.br

Submitted: October 29, 2008 - Revised and accepted: June 05, 2012 


\section{INTRODUCTION}

The use of the elastomeric separators in orthodontic practice is quite frequent, since the banding process of the upper and lower molars are, in most cases, the starting point of orthodontic treatment.

There are basically three types of separators: The brass wire, the orthodontic spring wire (or stainless steel), and the elastomeric separators. This research was directed to the last one, because it is clinically the most used, easy to use, handle and store.

There are case reports of localized periodontitis resulting from the loss of elastic separators in the subgingival space, which may cause serious problems, such as vertical resorption of alveolar bone, and also loss of fibers and periodontal ligaments.

For the reasons above exposed, the elastic separator radiopacity is considered so important, allowing it to be located by a periapical radiograph of the area in which it was previously positioned.

In this experimental trial, six brands among domestic and imported, were tested, namely Abzil, American Orthodontics, Dentaurum, GAC, GH and Morelli; for which radiopacity, and through physical traction tests, the plasticity of elastic separators were evaluated.

There are few studies about elastic separators in the literature. The published studies about elastomers usually report the physical behavior of elastic chains, which, despite being composed by the same material as the elastic separators, have a pretty different clinical application. ${ }^{1}$

Elastomer is a general term that includes macromolecular materials, which after a substantial defor- mation, quickly returns to its original dimensions. ${ }^{2}$ The first material known as rubber (or caoutchouc, of "kautchuc" word of upper Amazon indigenous language) is the polyisoprene, latex, collected from the tree sap of Heveabrasiliensis, for this reason, it is known as natural rubber ${ }^{7}$. The natural rubber was the first elastomer known and used on an industrial scale until 1927.,2,5

The first elastics used in orthodontics by Baker, Angle and Case, in the early twentieth century, were derived from natural rubber and had an excellent resistance to fatigue and slit propagation, high resilience, low hysteresis and effective adhesion to metals ${ }^{7}$. Hysteresis refers to the phenomenon observed in elastic bodies submitted to effort, as these do not quickly and fully recover their original form after ceasing the elastic stress, resulting in a slight deformation, which may be permanent. The natural rubber wasn't very useful until the vulcanization discovery, attributed to Charles Goodyear, in the United States, and Thomas Hancock, in England, increasing vertiginously the use of natural rubber. ${ }^{1,2,3,11,18,19}$

With the wide use of elastomers, the synthetic elastomers or polymers of synthetic rubber were developed by petrochemists in 1920., ${ }^{1,2}$ The synthetic rubber is the group of compounds produced in order to reproduce the properties of natural rubber. ${ }^{11}$

The vulcanization is the formation of crosslinks in the individual polymer molecules, converting a viscous entanglement of molecules with long chains in an elastic three-dimensional network, linking chemically (by means of crosslinking) these molecules at

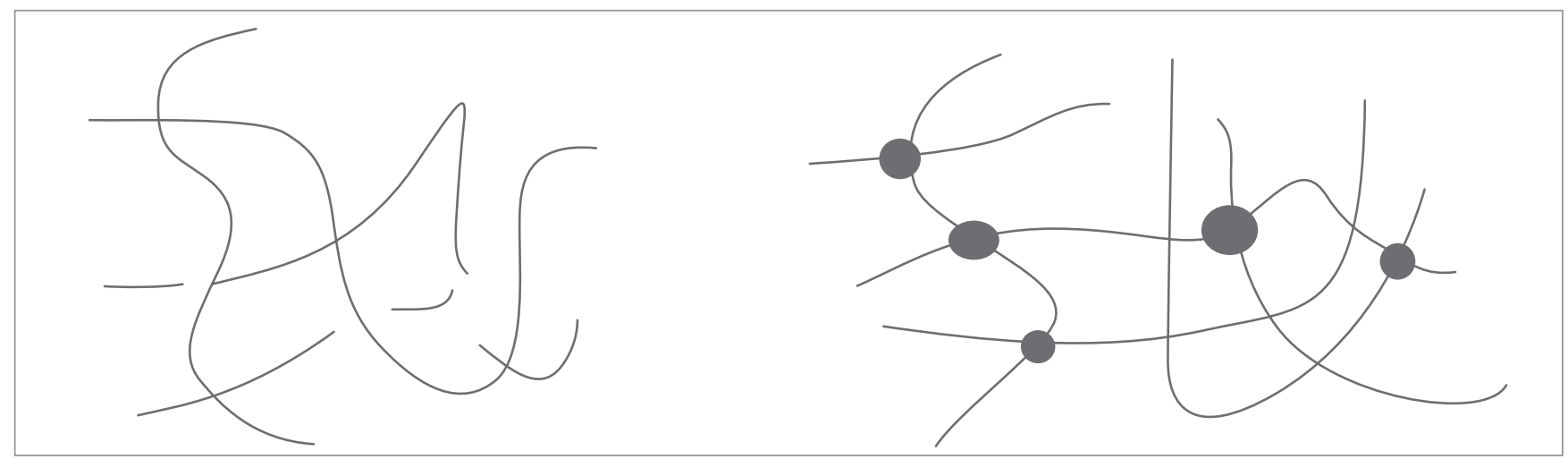

Figure 1 - Schematic representation of long polymeric chains before and after cross-links, transforming the tangle of molecules into a three dimensional elastic net. 
various points along the chain, with proportional resistance to the amount of those bonds ${ }^{3,9,15,17,18,19}$ (Fig 1).

Nowadays the use of elastic separators is widely spread, not only for their convenience in handling, but also due to storage, easy acquisition, different sizes and prices. The elastic separator has the function of performing spacing between the teeth, providing, therefore, a better band adaptation to the tooth and better comfort for the patient during this procedure.

There is general consensus that a proper separation between the teeth is required for adequate band adaptation. ${ }^{6}$ In 1907, Angle discussed the need to separate the teeth using a brass wire ligature, which was passed under the contact and, then, over the contact, after that, the ends were firmly twisted together. ${ }^{6}$

In 1914, Dalton set the space between the teeth by means of a thin strip of rubber separation, but he advised that the rubber should be kept in place for only one day, since it could slide across the contact, entering into the interproximal space, causing injury to the gingiva. ${ }^{6}$

In 1921, Calvin Case advocated the use of a separation strip, which was a flax waxed and wrapped wire, wrapped up around the contact. According to the author, the strip should be left just for 24 hours, and then should be replaced if the separation wasn't enough. ${ }^{6}$

In 1940, Oliver expanded the reasons why it is necessary to have enough space between the tooth to be banded and adjacent teeth, and listed the following reasons: ${ }^{6}$

- To reduce physical pain at the lowest possible level.

- To prevent injury to the tooth structure by excessive pressure.

- To prevent injury to soft tissue by having to force the banding material in position.

- To reduce patients' physical and mental tension when having the banding material conveniently carried to position.

- To prevent the banding material distortion, without having to force it improperly to the position during band construction.

Although there is a variety of available separators, the principle is the same in each case: To place an object or a wedge between teeth to force them to separate for the necessary time, in order to occur the tooth's initial movement, so that the teeth slightly separate from each other between the appointments, adequately for a proper band adaptation. ${ }^{16}$

Nascimento et al, ${ }^{12}$ reported that the most discomfortable phase during orthodontic treatment was the separation, and that discomfort reached the peak 24 hours after the separator insertion, decreasing drastically on the third day and being close to zero on the sixth. ${ }^{12}$

According to Proffit and Fields, ${ }^{16}$ the three main methods used for the posterior teeth separation are:

- Brass wire: Which must be twisted around the contact point and left in position for 5-7 days.

- Separation springs: Perform a scissor action above and below the contact point, opening the required space for the bands in approximately one week.

- Elastic separators: Which involve the contact point, pressing the teeth for a few days to occur separation.

The elastic separator is positioned with the aid of two segments of dental floss, it should be positioned with one part below and the other above the contact point between the teeth. According to Proffit and Fields ${ }^{16}$, they should not be left in position for more than two weeks. From the standpoint of patient's comfort, they must be maintained for at least 3 days and preferably for 7 days, prior to attempt of banding the tooth $^{6}$, which is enough time to promote the separation between the teeth.

On several occasions the patient returns to the office without the elastic separator. There are data in the literature where McQuillin (1870 apud Finkbeiner, Nelson, Killebrew ${ }^{4}$ ) reported damage to the periodontium by improper use of elastic ligatures. When misused, the elastic ligature can slide down the gingival margin and contribute to a low and painless detachment of the periodontal ligament. The result is a deepening of the gingival sulcus, with possible loss of periodontal support. ${ }^{20}$ The elastic ligatures submerged gingivally serve as foreign bodies, perpetuating the periodontal ligament detachment from the alveolar bone, so the clinicians should fully investigate the problem, to be sure that all the elastic ligatures were removed, and thus prevent further damage. ${ }^{4}$

In view of damage caused to periodontal tissues by orthodontic elastic ligatures subgingivally retained, Vandersall and Varble ${ }^{21}$ advised in 1978 that an extreme caution should be taken with their use 
until a harmless radiopaque medium could be safely added to them. In view of previous reports, the radiopacity of dental materials is a desirable property, because it helps to detect radiographically materials' remains present in the oral tissues or that may have been inadvertently swallowed or even more serious, inhaled ${ }^{14}$.

There are already radiopaque elastic separators available on the market. Many substances can be incorporated during the manufacturing process to make them radiopaque. The two most commonly used substances are barium and bismuth.

The evaluation of elastic separators' radiopacity is a complex procedure, because the radiopacity depends, among other things, on the quality of the X-ray beams.

\section{MATERIAL AND METHODS}

All materials used, such as elastic separators, radiographic films, dental developer and dental fixer solutions, were purchased directly from their dealers, in closed and sealed containers, within the validity period, and were stored according to manufacturers' specifications.

\section{Physical traction tests}

The machinery used in testing physical traction was provided by Inser (Industry, Trade and Services Ltda.), located in Sorocaba, São Paulo, where this experimental trial was conducted.

The elastics were divided into two groups according to the type of manufacturing process: Modular elastic

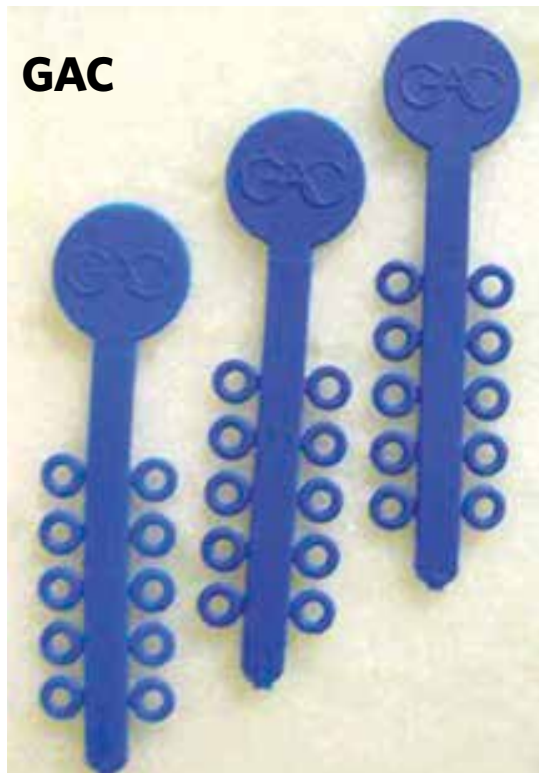

\section{Morelli M. Blue}

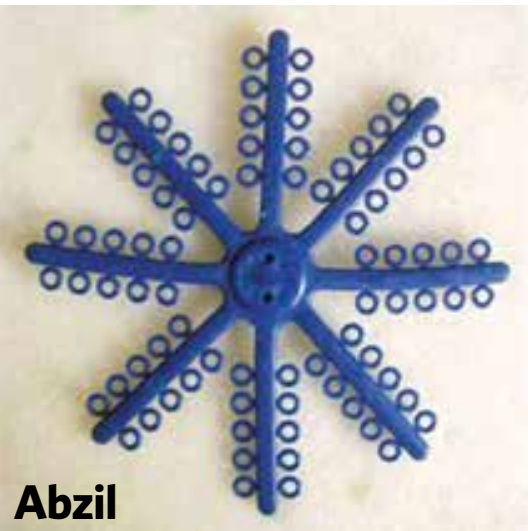

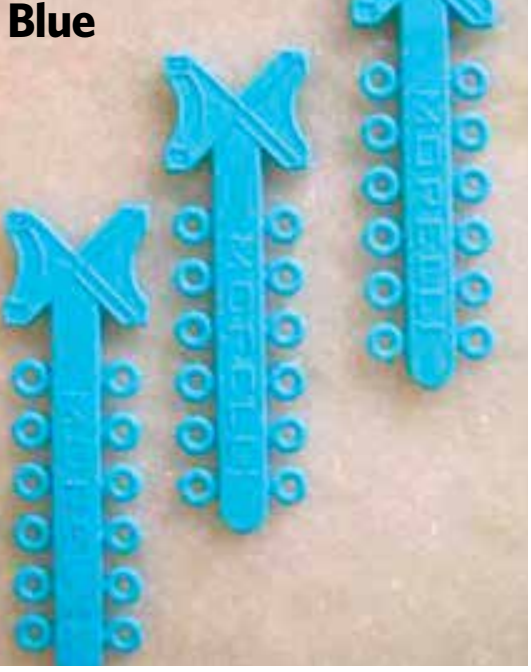

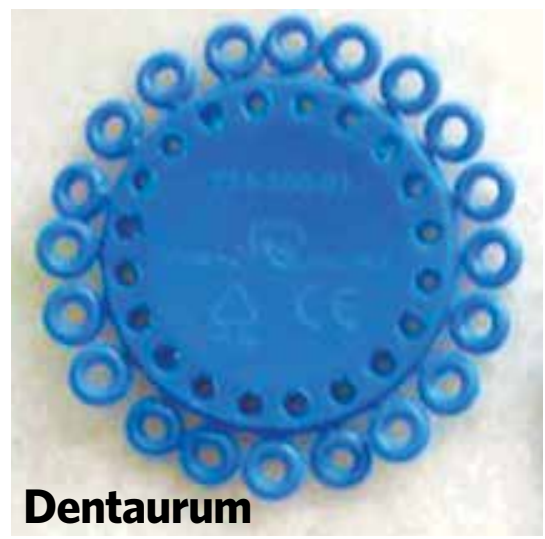

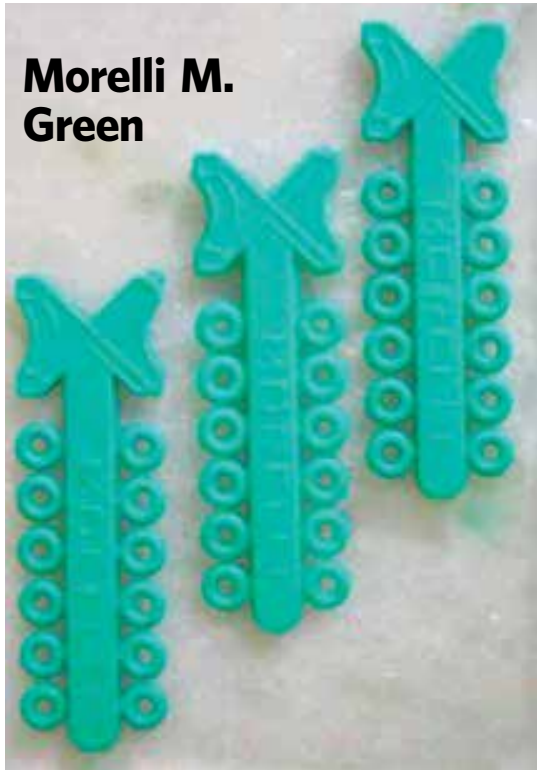

Figure 2 - Modular elastic separators. 

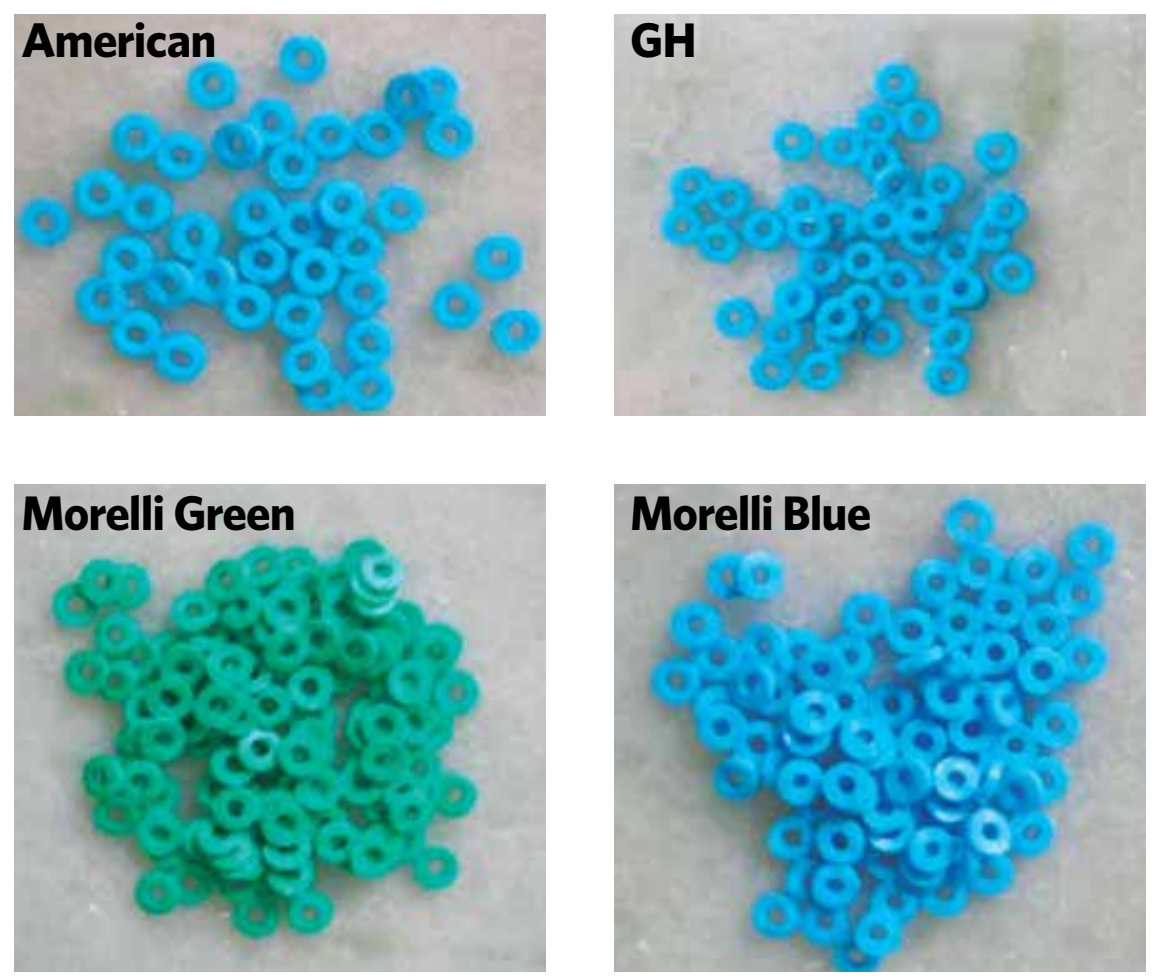

Figure 3 - Extruded elastic separators.

separators: Abzil, Dentaurum, GAC and Morelli (Blue and Green) and extruded elastic separators: American Orthodontics, GH and Morelli (Blue and Green), thus giving a total of nine samples (Figs 2 and 3).

Five elastic separators were randomly selected from each sample, and the initial inner diameter was measured with a Westover trinocular microscope coupled with a Digital Camera Tec Voz, model Tec 420, providing photos from the elastic separators, with the inner diameter measurements enlarged by 15 times, generating an average for each sample.

The environmental conditions during the tests were in accordance with the German Standard DIN, number 13901, item 5.3, sub item 5.3.1, corroborated by the ISO / FDIS (The International Organization for Standardization), number 21606, where the tests should be carried out at $23 \pm 2^{\circ} \mathrm{C}$ $\left(73.4 \pm 35.6^{\circ} \mathrm{F}\right)$, relative humidity of $50 \% \pm 10 \%$ and with a test speed of $100 \mathrm{~mm} / \mathrm{min}^{8}$

Before conducting the tensile test, the universal testing machine (Emic, DL-500) was calibrated with a few samples to eliminate possible errors and adjust the stretching parameters in accordance with the inner diameter of each sample. The stretching test of 3 times the elastic separators' inner diameter (ID)was performed. A load cell of $10 \mathrm{~kg}$ (kilograms) was used for the tests.

After adjustment of universal testing machine by means of pilot tests the tensile testing with all available samples was initiated. For each test 10 elastic separators were used, each one was placed in the testing machine just once, running, therefore, only one test.

The elastic separators were removed from their respective storage packs (one at a time) and positioned vertically in the grips of testing machine,${ }^{8}$ where they were stretched to 3 times their inner diameter in the universal testing machine Emic DL-500, generating graphs in the Tesc software, version 3.01, with the information of each performed test.

After the stretching test of 3 times the inner diameter, the elastic separators were stored in plastic bags properly identified for the further capture with the Westover trinocular microscope. The photos were taken after the sequence tests for the extruded separators', proceeding in the same way with the modular separators. These photos contained the measures of the inside diameter of 5 elastic separators randomly chosen, in order to compare them with the initial photos and get the deformation percentage of elastic separators. 


\section{Radiographic test}

The radiographic part of this experimental work was performed in São Paulo at the Paulista Association of Dental Surgeons (APCD), Sorocaba. Prior to perform the radiographs, the last calibration date of the radiation emitted by the $\mathrm{X}$-ray device was verified, and some $\mathrm{x}$-ray tests were performed to adjust the exposure time required for the radiographs.

The radiation source was a dental X-ray machine with a total filtration equivalent to $2 \mathrm{~mm}$ aluminum. Periapical films of group E were used. According to Langlais and Langland, ${ }^{10}$ the greater the film sensitivity, the lesser the radiation time required to obtain a good contrast X-ray.

The radiographs were taken with the elastic separators attached directly on the radiographic film using adhesive tape. The separators arrangement in radiographs were made asymmetrically, such as that shown in Figure 4, to prevent the error possibility in the identification of each elastic separator in the radiograph after development. The films were exposed for 0.3 seconds at $15 \mathrm{~mA}$ (milliamps) and $75 \mathrm{kV}$ (kilovolts). A radiographic incidence was conducted for extruded separators and another for the modular ones (Fig 4).
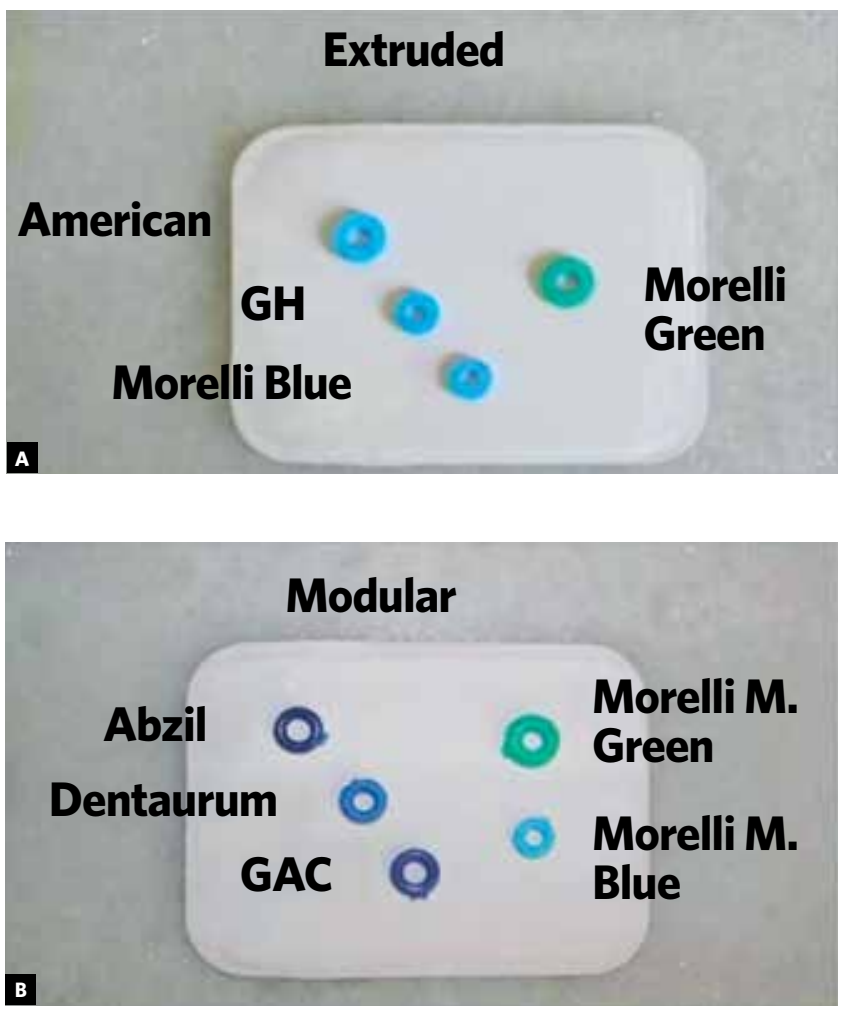

Figure 4 - Photographs with the placement of the extruded and modular elastic separators on the periapical films.
After the film exposure to X-rays, they were developed in a dark portable chamber, observing the proper time in each container, namely, dental developer solution, water and dental fixer solution, following this sequence.

The periapical radiographs were analyzed with the aid of a light box in a dark room in order to improve visual acuity in the analysis of radiopacity.

\section{RESULTS \\ Physical traction tests}

Based on the data collected in pre and after stretching pictures, it was possible to evaluate the amount of deformation in millimeter and percentage when elongated to 3 times the inner diameter. When stretched 3 times their inner diameters, the elastic separators should return to their original dimensions, simulating the clinical reality during placing.

The separators inner diameter in the images is obtained as follows: Having the radius (R), which is calculated from three points marked by a cross, and multiplying the radius value by 2 , the result is the elastic separator's inner diameter.

\section{Extruded elastic separators}

Among the extruded type of separators with respect to stretching to 3 times the inner diameter, those who suffered the greatest deformation percentage were the Morelli Blue separators with $103.00 \%$, which represents about $0.052 \mathrm{~mm}$, followed by the $\mathrm{GH}$ separators with $100.46 \%$ of deformation, which equals $0.009 \mathrm{~mm}$. Followed by the Morelli Green separators with $99.07 \%$ of deformation, equals to $-0.021 \mathrm{~mm}$, and finally suffering the least distortion are the American Orthodontics separators with $96.67 \%$, representing approximately $-0.073 \mathrm{~mm}$. After elongating the extruded separators to 3 times their inner diameter, we have in decreasing order of plasticity: American Orthodontics, Morelli Green, GH and Morelli Blue. These results ensure that even when stretched 3 times their inner diameter, the extruded separators did not suffer plastic deformation, since they have returned to their dimensions after stretching and kept their characteristics and properties, being able to play their role in the teeth separation (Fig 5).

Two results draw attention for being negatives values, which means that the separators were elongated 

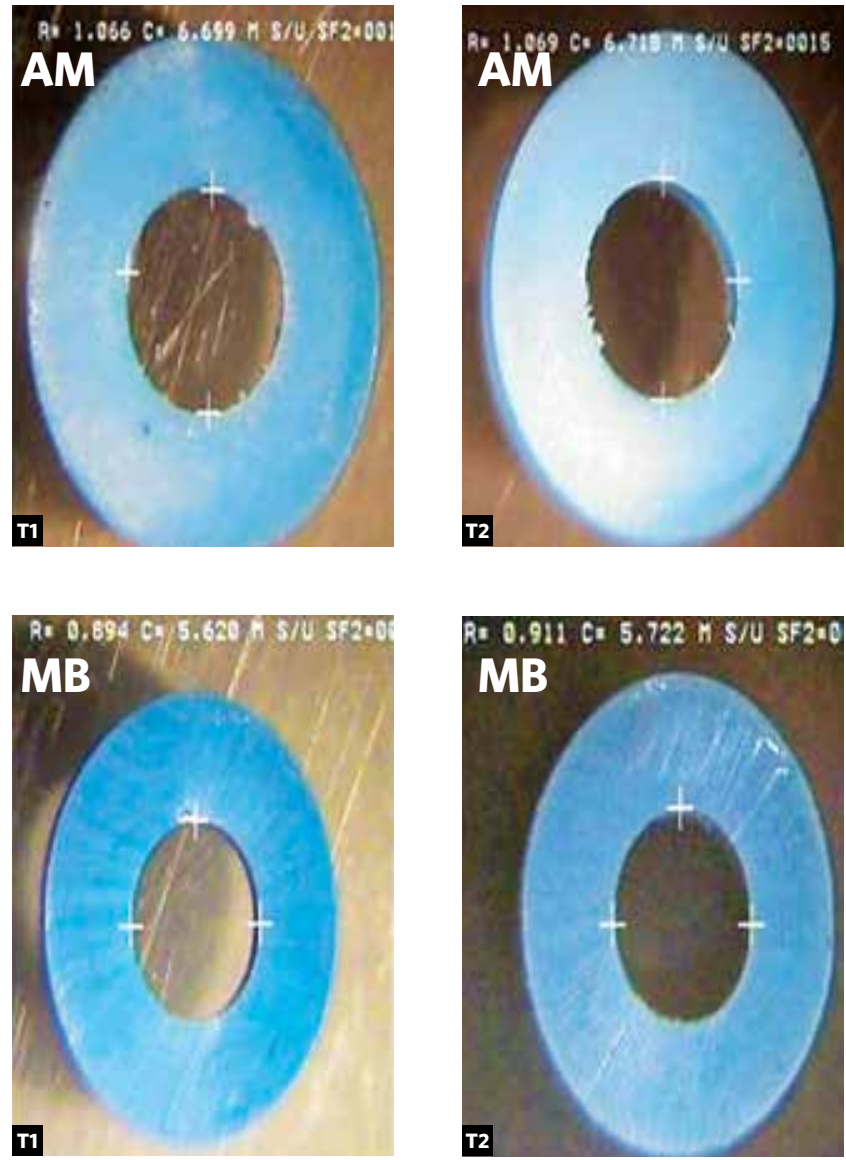
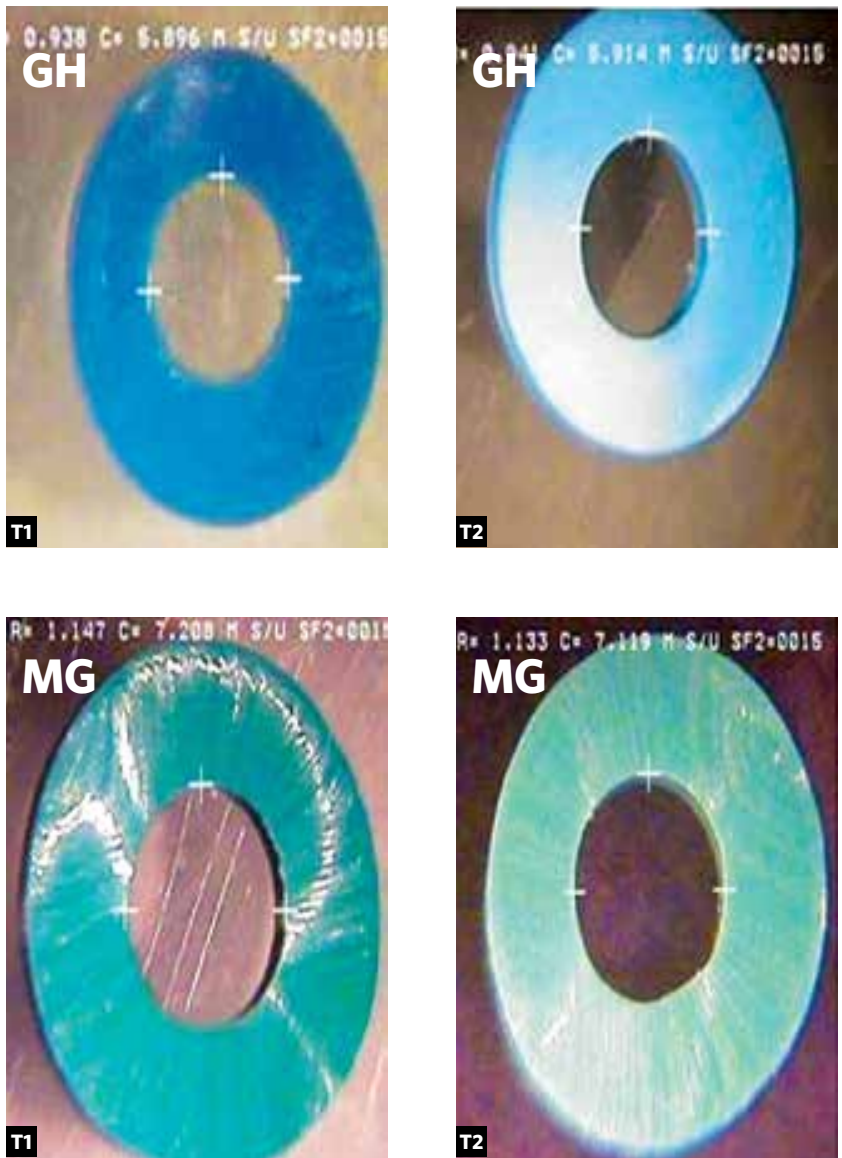

Figure 5 - Extruded separators before stretching (1) and 3x ID (2). AM: American Orthodontics, MB: Morelli Blue; MG: Morelli Green.

three times their inner diameter (ID) and returned $0.021 \mathrm{~mm}$ (Morelli Green) and $0.073 \mathrm{~mm}$ (American Orthodontics) beyond their original diameter, ending up with a slightly reduced inner diameter. Such evidence is unnoticeable to the naked eye, only being detected through 15 times magnification. It is also worth mentioning that the results presented for extruded separators Morelli Green and American Orthodontics are due to the average obtained from the 5 selected samples after inspection in a trinocular microscope, and it is known that while there is a standard, there are differences in sample sizes in of a single batch, which does not affect the validity of this work, provided that such variations are within the standard deviation stipulated by DIN or ISO standards followed by the manufacturer. According to standard DIN, the tolerance for separating rings with up to $3 \mathrm{~mm}$ inner diameter is $\pm 0.15 \mathrm{~mm}$, so we conclude that the measures presented by the extruded separators Morelli Green and American Orthodontics are within the standard deviation.

\section{Modular elastic separators}

Regarding the modular elastic separators group, referring to the stretching of 3 times the inner diameter, the following results were obtained: Morelli Modular Blue had $110.75 \%$ of deformation, representing about $0.172 \mathrm{~mm}$; Abzil suffered $108.07 \%$ of deformation, equivalent to $0.190 \mathrm{~mm}$; Dentaurum presented $103.60 \%$ of deformation, representing about 0.072 $\mathrm{mm}$; GAC had $102.68 \%$ of deformation, which is about $0.062 \mathrm{~mm}$ and, finally, Morelli Modular Green with $102.08 \%$ of deformation, which equals to $0.046 \mathrm{~mm}$. Only the Abzil and GAC samples of modular separators showed mild signs of plastic deformation which were detected in the images obtained with the microscope. Plastic deformation means the material's inability to return to its original shape. The Morelli Modular Green and Dentaurum elastic separators returned to their original measures, in view of the $\pm 0.15 \mathrm{~mm}$ tolerance indicated by standard DIN for separating rings. The Morelli Blue modular separator showed deformation a little beyond that stipulated by 
the standard DIN, but no signs of plastic deformation. The Morelli Green modular elastic separator had the lowest deformation, in percentage and millimeters, when stretched 3 times its inner diameter. Regarding their plasticity, modular separators were ranked as follows: Morelli Modular Green, Dentaurum, Morelli Modular Blue, GAC and Abzil (Fig. 6).

From what could be extracted from the above information, it is possible to conclude that the modular separators showed higher deformation, in percentage and millimeters, than the extruded type when elongated to 3 times their inner diameter. The modular separators show a plastic aspect, while the extruded type seem more elastic (rubber). For this reason, the deformation rate, unnoticed to the naked eye in extruded separators, is easily conspicuous in the modular ones, for characteristics such as shape alteration and the grip marks from the universal testing machine.

\section{Radiographic test}

The radiographic analysis had the following result: In the extruded separators group, composed by
American Orthodontics, GH, Morelli Blue and Morelli Green, only the American Orthodontics and GH separators revealed to be radiographically detectable (Fig 7).

In the modular separators group, namely Abzil, Dentaurum, GAC, Morelli Modular Blue and Morelli Modular Green, the separators that had detectable levels of radiopacity were Abzil, Dentaurum and GAC (Fig 8).

Knowing the importance of radiopacity in the elastic separators, the only reason that could discourage their use is the risk of toxicity, however the toxicity evaluation of the tested separators was not the emphasis of this experimental trial.

Correlating the results concerning the plasticity and radiopacity, the separators that showed the most satisfactory results were, among the extruded separators, American Orthodontics and GH, and among the modular separators, GAC and Dentaurum.

Further researches should be conducted about the toxicity of materials used to provide radiopacity to elastic separators, considering that this would be the only reason not to produce radiopaque separators, since they did not show changes in their properties.
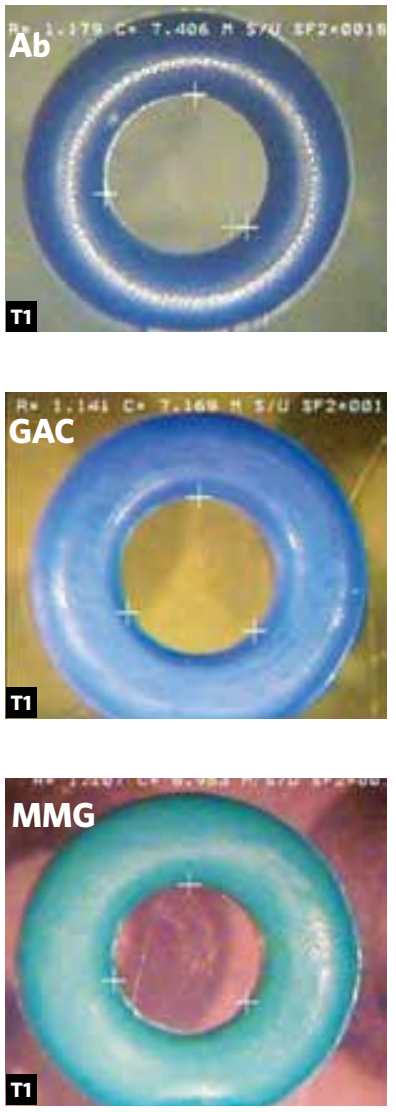
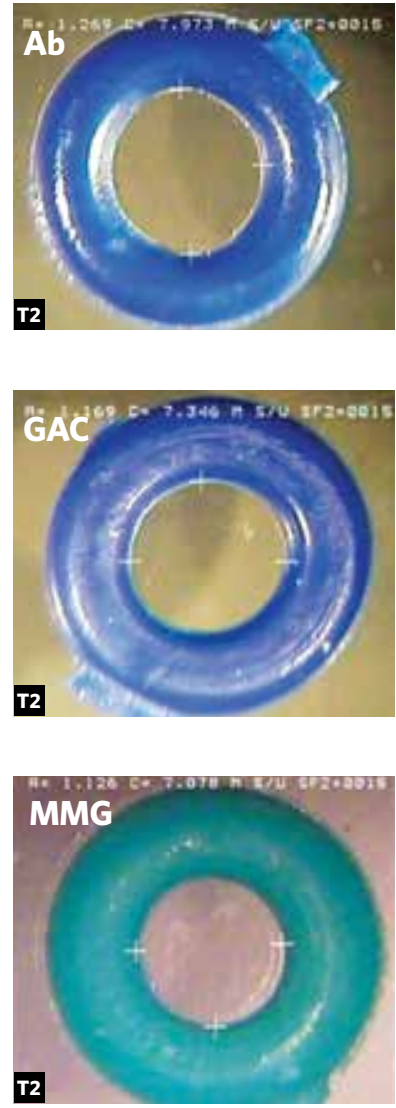
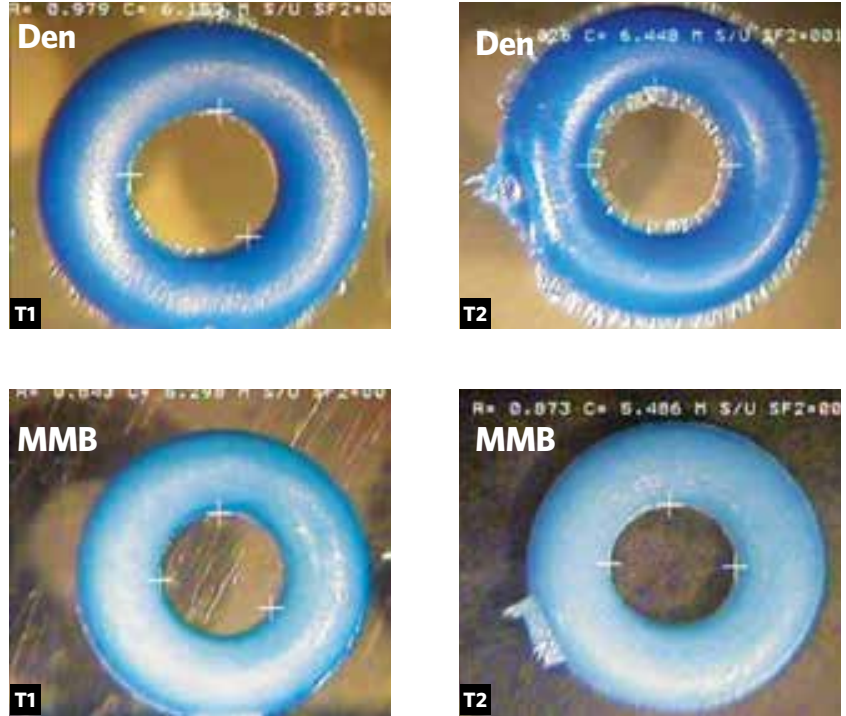

Figure 6 - Modular separators before stretching (1) and 3x ID (2). Ab: Abzil, Den: Dentaurum; MMB: Morelli Modular Blue; MMG: Morelli Modular Green. 

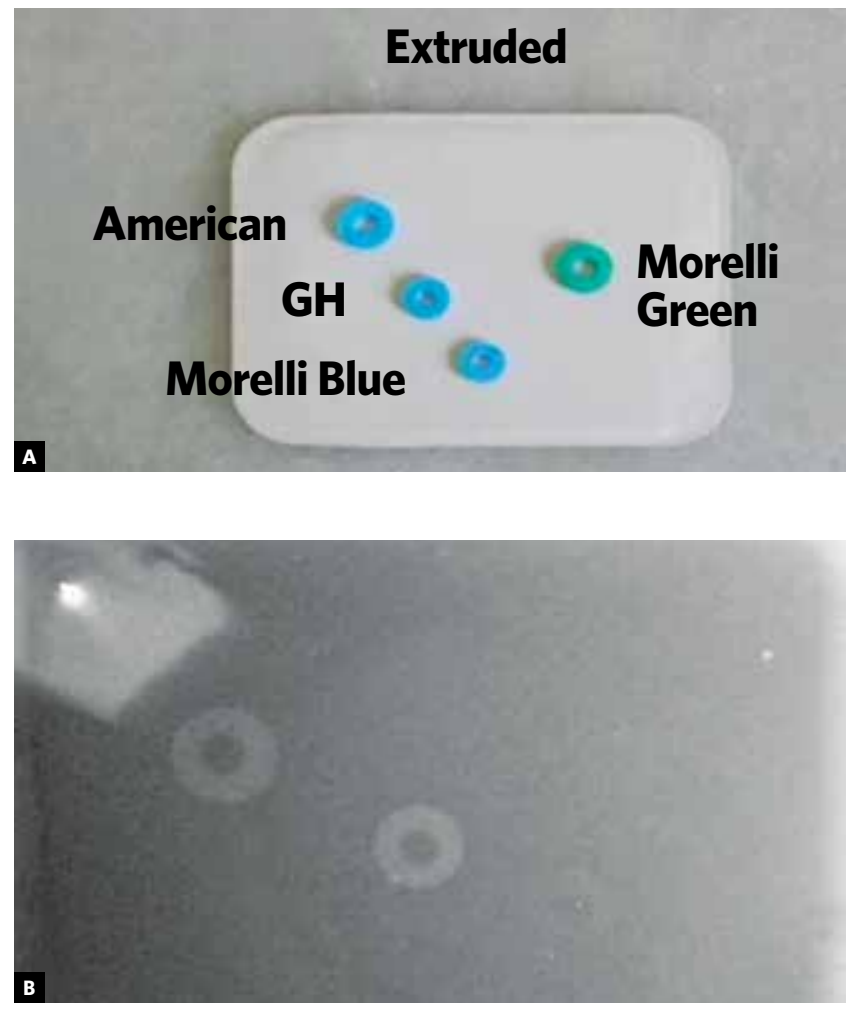

Figure 7 - Photographs of the placement of the extruded separators on the radiographic film and periapical radiography of these separators.

\section{CONCLUSIONS}

Given the informations obtained in this study, it can be stated that:

1» When stretched to 3 times their inner diameter, the extruded separators American Orthodontics, GH, Morelli Blue and Morelli Green and the modular separators Dentaurum, Morelli Modular Green and Morelli Modular Blue showed elastic deformation, returning to their original inner diameter. The modular separators Abzil and GAC suffered permanent plastic deformation.

2» In descending order of plasticity, the extruded separators, when elongated to 3 times inner diameter, are ranked as follows: American Orthodontics, Morelli Green, GH and Morelli Blue. Regarding plasticity of the modular
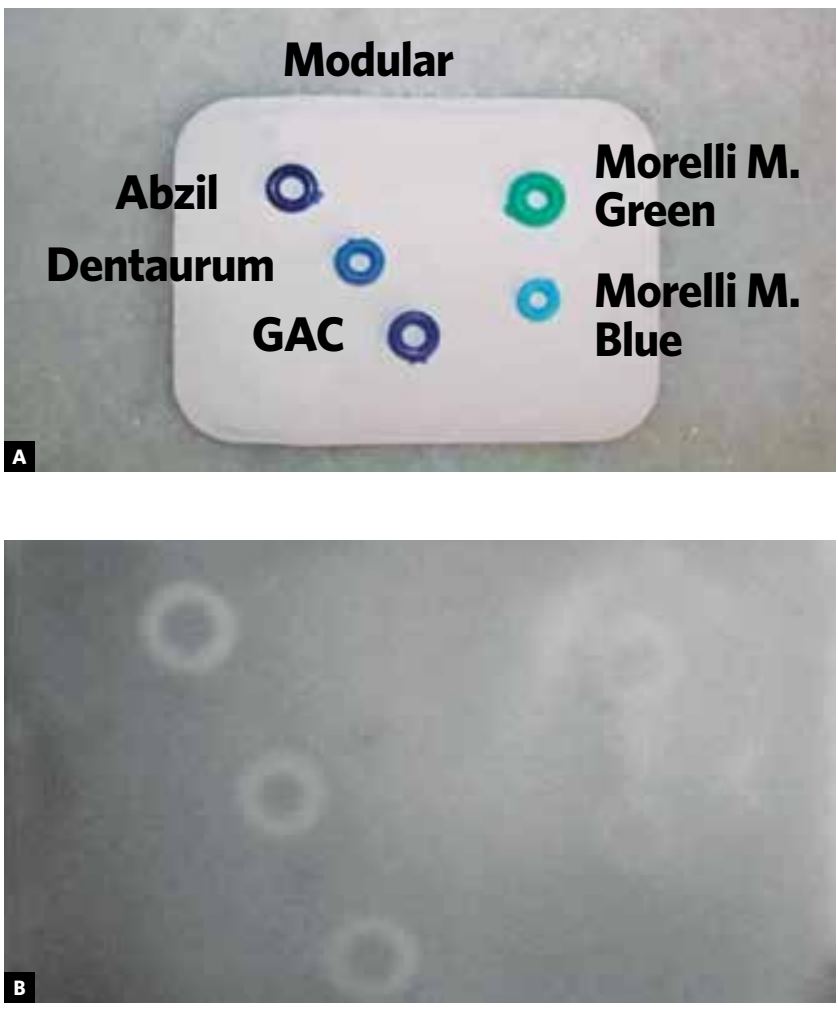

Figure 8 - Photographs of the placement of the modular separators on the radiographic film and periapical radiography of these separators.

elastic separator group, they are ranked, in descending order as follows: Morelli Modular Green, Dentaurum, Morelli Modular Blue, GAC and Abzil.

$3 »$ With respect to radiopacity, the separators from Abzil, American Orthodontics, Dentaurum, GAC and $\mathrm{GH}$ revealed to be radiopaque.

4» Correlating the results concerning plasticity and radiopacity, the separators that had the most satisfactory results on both fronts were, among the extruded separators, American Orthodontics and $\mathrm{GH}$, and among the modular separators, GAC and Dentaurum.

5» The elastic separators that displayed radiopacity showed consistent results with the non-radiopaque separators for the physical traction tests. 


\section{REFERENCES}

1. Abrão L, Mendes AM, Artese F. Avaliação da intensidade das forças liberadas por ligaduras elásticas de diferentes cores. Rev Clín Ortod Dental Press. 2007;6(2):92-7.

2. Baty DL, Storie DJ, von Frauhonfer JA. Synthetic elastomeric chains: a literature review. Am J Orthod Dentofacial Orthop. 1994;105(6):536-42.

3. Costa HM, Visconte LLY, Nunes RCR, Furtado CRG. Aspectos históricos da vulcanização. Polímeros: Ciência e Tecnologia. 2003;13(2):125-9.

4. Finkbeiner RL, Nelson LS, Killebrew J. Accidental orthodontic elastic band-induced periodontitis: orthodontic and laser treatment : case reports. J Am Dent Assoc. 1997:128(11):1565-9.

5. Gomes MM. Introdução aos polímeros, elastômeros e borrachas. Rubberpedia: Portal da indústria da borracha [Acesso 2007 Ago 21]. Disponível em: www. rubberpedia.com.

6. Hoffman WE. A study of four types of orthodontic separator. Am J Orthod Dentofacial Orthop. 1972;62(1):67-73.

7. Hofmann W. Rubber technology handbook. Hanser, New York, 1989. In: Gomes MM Introdução aos polímeros, elastômeros e borrachas. Rubberpedia: Portal da indústria da borracha [Acesso 2007 Ago 21]. Disponível em: www.rubberpedia.com.

8. Huget EF, Patrick KS, Nunez LJ. Observations on the elastic behavior of a synthetic orthodontic elastomer. J Dent Res. 1990;69:496-501.

9. Manual for the rubber industry. Kempermann T, Koch S, Summer J. Bayer AG, Development Section Leverkusen; 1993.

10. Langland $\mathrm{OE}$, Langlais RP. Princípios do diagnóstico por imagem em odontologia. 1’a ed. São Paulo: Ed. Santos; 2002. p. 85-143.

11. Monezi C. Fabricação de borrachas. Universidade Presbiteriana Mackenzie; 2002 [Acesso 2007 Ago 21]. Disponível em: http://www.colegiosaofrancisco.com.br/ alfa/historia-da-borracha/producao-de-borracha.php.
12. Nascimento JE, Leite MAP, Bozelli JV, Sato FRL, Sato K. Avaliação clínica dos medicamentos ibuprofeno e paracetamol quanto à efetividade analgésica e interferência na movimentação dentária ortodôntica. Rev Assoc Paul Espec Ortodon Ortop Facial. 2005;3(1):4-15.

13. Nautilus. Tabela periódica [Acesso 2007 Nov. 13]. Disponível em: http://nautilus. fis.uc.pt/st2.5/scenes-p/elem/e08300.html.

14. Parissis N, lakovidis D, Chirakis S, Tsirlis A. Radiopacity of elastomeric impression materials. Aust Dent J. 1994;39(3):184-7.

15. Pinheiro EG. Modelos numéricos aplicados à vulcanização de pneus [dissertação] [Acesso 2007 Ago 21]. São Paulo (SP): Universidade de São Paulo; 2001. Disponível em: http://www.teses.usp.br/teses/disponiveis/3/3132/tde25082003-090611/.

16. Proffit WR, Fields HW Jr. Ortodontia contemporânea. 3aㅡ ed. Rio de Janeiro: Guanabara Koogan; 2002

17. Sardella A, Mateus E. Dicionário escolar de química. São Paulo: Ática; 1981

18. Shreve RN, Brink JA Jr. Indústrias da borracha. In: Indústria de processos químicos. 4 a ed. Rio de Janeiro: Guanabara Koogan; 1977. cap. 36.

19. Stern HJ. History. In: Blow CM. Rubber technology and manufacture. London: Newnes-Butterworths; 1975. cap. 1

20. Vandersall DC. Localized periodontitis induced by rubber elastic: report of case. J Am Dent Assoc. 1971:83(6):1326-8.

21. Vandersall DC, Varble DL. The missing orthodontic elastic band, a periodonticorthodontic dilemma. J Am Dent Assoc. 1978;97(4):661-3. 